O S M I IKOLA

\title{
Ensimmäinen ja toinen
}

Y. H. Torvosen Suomen kielen etymologisen sanakirjan (SKES) I osan mukaan kuuluvat ensi-sanan kanssa yhteen mm. seuraavat suomen sanat: ennen, ensin, enne; ennus, murt. ennos 'enne, ennakikotieto', ennustaa; ensikki, enso 'maanantaina, viikon ensimmäisenä (arki)päivänä syntynyt lehmä'; ensimmäinen; *enta : ennalla (an), -lle (en), ennalta, murt. *entä : ennällään, -lleen, johd. *ento : ennollansa 'entisellään', ennolla, -lta 'etukäteen', ennakko, murt. ennäkkö, ennakoita, "entuus : entuudesta(an); entinen. Suomen kielen ulkopuolelta SKES luettelee vastineita ainoastaan lähisukukielistä sekä lapista, johon sanue on lainautunut suomesta. Lähisukukielistä mainittakoon seuraavat sanueen edustajat: karj.-aun. enzzi, enzi (ende-); eñ̌imäine, enzimäine; end'ine; lyyd. eez, eńd'ž, eńš 'ensi', ende 'ennen'; end żimaine, -mäińe, eeźimaine, -mäine; veps. ende, -e 'ennen', endeglē, endegläšt' 'toissa päivänä'; endustada; end'źńe (part. endišt), enźne (gen. eńtšen); vatj. enne 'ennen', ennegl $\overline{\ddot{a}}$ 'toissa päivänä', entin; vir. enne 'ennen, muinoin; äsken', ennist 'taannoin, äsken'; ennustada 'ennustaa (pilailla), hätäillä, ennättää edelle'; eesik; murt. ennalt 'ennemmin'; endine 'entinen, muinainen'; liiv. enst (Sal.)

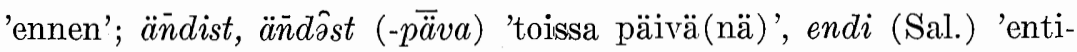
nen'.

Vepsän, vatjan, viron ja liivin 'ensimmäistä' merkitsevä sana perustuu SKES:n mukaan esi-vartaloon: veps. eźmeine, eźmānie, vatj. esimein, vir. esimene, liiv. $e^{\prime}$ žmi, $e^{\dagger} i \ddot{z} m i$. Myös suomen murteissa esiintyy suhteellisen laajalti esi-vartalo ensi-vartalon synonyymina, esim. PunL' kuali koht esivuanna, Suoni esiks, esimmäinen, Oriv eșin 'en-

1 Käytän Suomen pitäjien nimistä tavanomaisia lyhennyksiä; ks. Vir. 1950 ss. $427-428$. 
sin', Län esimmäinen (VIRTARANTa Länsiyläsatakuntalaisten murteiden äännehistoria I, 1946, s. 275), Erä esistä, Pälkä esivuatta 'ensimmäistä vuotta' (VIRTARANTA Hämeen kansa muistelee, 1950, ss. 310, 182), Urj Kyl Aka esimmäinen, esistään, esin (KanNisto Suomi III $14: 2$ s. 38 ), Kyl esi viikolla 'ensi viikolla' (KanNisto Suomi III 20 s. 274), Kiur esinnä 'ensin(nä)' (Vir. 1934 s. 154). Vieläpä Kalevalassakin 25:519: Isännän esinnä kiitin, Siïtä ehtoisen emännän. Osassa tällaisista esi-tapauksista on kuitenkin nähtävästi esi- < ensi-.

József Budenz yhdisti ensi-sanan etymologisesti esi-vartaloon (Magyar-ugor összehasonlító szótár, 1873-81, ss. 293, 778, 780), samoin hänen mukaansa eräät muutkin tutkijat, mutta uudempi tutkimus on erottanut nämä vartalot toisistaan. Ensi-sanalle ori aikoinaan esitetty toinen, aina samojediin saakka ulotettu etymologia: tšerKB $a^{\prime} n z \hat{\partial} l, \mathrm{U} o^{\circ} n d^{\prime} \grave{z}_{\grave{\partial}} l$ 'edessä oleva, etuosa, etu-, esi-' / votj.

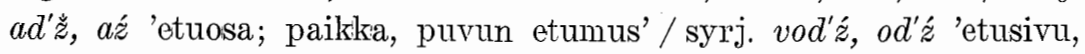
edusta' / ?ostj. unža- / ?unk. eggy, egy 'yksi' / ?samO ě̌ er, easeroi 'ensimmäinen' (SETäLÄ FUF 2 ss. 230, 243, FUF 12 Anz. s. 98, SUSA 30:5 s. 94 ; samoin Wichmann Magyar Nyelv 4 s. 307, Szinnyei Magyar nyelvhasonlítás, 5. p., s. 44, Finnisch-ugrische Sprachwissenschaft, 1910, s. 45, Gомвосz-MeLICH Magyar etymologiai szótár, I kötet, s.v. 1. $\ddot{e} g y$ ).

Y. H. Torvonen vuorostaan yhdisti mainitut tšeremissin ja permiläiskielten sanat toiseen suomen sanaan, nim. sanaan otsa, joka merkityksensäkin puolesta kyllä sopii niiden vastineeksi (FUF 19 ss. 29, 175, FUF 28 Anz. s. 202). Hänen käsitykseensä on yhtynyt K. B. WiKLUnd (SUST 67 ss. 407-, 410; ks. myös G. Bárczi Magyar szófejtő szótár s.v. egy; näin myös SKES II s.v. otsa).

Jos Torvonen ja WikLund ovat oikeassa, on ensi-sanalla vain ims. kieliin rajoittuva hyväksyttävä etymologia. Se selitysmahdollisuus, jonka seuraavassa esitän, ei ole kokonaan uusi, kuten tuonnempaa selviää. Sitä, että kuitenkin käytän asiasta puheenvuoron, perustelisin sillä, että suomalaiset tutkijat eivät ole huomatakseni missään yhteydessä edes maininneet tätä selitystä (niimpä SKES sen paremmin kuin HAKULISEN Suomen kielen rakenne ja kehitys -teoksen uusi painoskaan [SKRK², 1961] ei siitä mitään puhu) ja että luulen voivani valaista asiaa eräillä uusilla näkökohdilla.

Huomio kiintyy helposti siihen yhtäläisyyteen, joka vallitsee 
ensi-sanan ja muiden ordinaalilukusanojen (toinen-sanaa lukuunottamatta) alkuperäisen sananlopun välillä: ensi $<$ *enti $<*$ *ente kolmas $<<$ kolmansi $<*$ kolmanti $<* k o l m a n t e$ jne. Aivan odotuksenmukaista on se, että -nsi-loppu on pääpainollisen tavun jäljessä säilynyt siltä "kulumiselta", joka on tullut sen osaksi pääpainottomien tavujen jäljessä. Ensi-sanan lyhyemmyys selittänee osaksi senkin, että se toisin kuin muut järjestyslukusanat on taipumaton (vrt. HAKULINEN SKRK ${ }^{2}$ II $\S 32$ ). Kun yhtäläisyys on näin selvä, ei ole syytä ilman muuta tyytyä pitämään sitä sattumasta johtuvana. Jos otamme työhypoteesiksi, että kyseessä ei ole pelkkä sattuman leikki, niin ensi sisältäisi tuitun järjestyslukujen johtimen *-nte, jolle on esitetty vastineita kaikista suomalais-ugrilaisista kielistä, jopa samojedistakin (ks. esim. Szinnyei Magyar Nyelvhasonlítás ${ }^{5}$ s. 94, RAvil.A Vir. 1932 s. 376, Uotila SUST 65 s. 95, HAKuLINEN SKRK ${ }^{2}$ I § 52:18, Collinder Comparative Grammar of the Uralic Languages, 1960, s. 261; viimeksi RAviLA Suomalais-ugrilaisten kielten ordinaalit, teoksessa Verba docent, 1959, s. 82-). Vokaalisuhde ensi ennen ennakko, ennallaan selittyisi samoin kuin esim. suomi $\sim$ suomen suomalainen, vrt. myös vir. kolmas : kolmanda jne.; on pidetty mahdollisena, että ordinaalilukujen johdin on alkuaan ollut $a$-loppuinen (ks. OJansuU SUSA 30:17 ss. 13-16, Ravila Vir. 1939 ss. 107-112, $\left.\mathrm{H}_{\Lambda \mathrm{KULINEN}} \mathrm{SKRK}^{1} \mathrm{I} \S 52: 14, \S 23 \mathrm{~B}\right)$. Vokaalisointusuhdetta ennallaan, ennakko murt. ennällään, ennäkkö verrattakoon esim. suhteisiin kesä $\sim$ kesanto, kesakko; elää elanto, elatus.

O. A. F. Blomsted selitti jo lähes sata vuotta sitten, että ensisanassa piilee ordinaalilukujen johdin, mutta hänen selityksellään, jonka mukaan johdin tässä olisi liittyneenä esi- : ete- vartaloon (ete + nte $>$ edente $>$ e'ente $>$ eente $>$ ente, ks. Blomsted Halotti Beszéd ynnä sen johdosta Vertailevia Tutkimuksia Unkaxin, Suomen ja Lapin Kielissä, 1869, s. 67 alav. 4), on tuskin enää muuta kuin kuriositeetin arvo.

Sen sijaan GÁBor ORBÁN on esittänyt mielestäni hyvin huomionarvoisen ajatuksen siitä, mihin kantasanaan liittyneenä tämä johdin ensi-sanassa esiintyisi (A finnugor nyelvek számnevei, Bratislava 1932, s. 72): "azonban már az ensimäise-elötagját alkotó ensi *ente szórész is összetétel; bizonyára a már tárgyalt f. *e- mutatónévmásnak a sorszámnévi -nte képzővel ellátott alakja. A térszemléletben a rámutatás sonképzetalkotó functiót eredményezett, s így lett a jelen 
esetben a demonstrativ elemekböl ordinale; _ _.” Tämän mukaan olisi siis kantasanana pronominivartalo $e$ - Kyseessä on uralilaisesta kantakielestä saakka periytyvä demonstratiivinen pronominivartalo, joka suomessa esiintyy mm. sanoissa ellen, ellet jne. (< ellä en, ellä et), es 'jos, vaikka' (Agr.), etenkin, että, vrt. myös vir. iga, murt. egä, ega 'joka' (< *ekä), embkumb 'jompikumpi'; Hakulinen on verrannut tähän myös sanaa ehkä (SKRK ${ }^{2}$ I § 58:2). Vrt. pronominivartaloihin jo-, ku-: jollen jne., jos, joten(kin), jotta, joka, jompikumpi; kuten, kuka, kumpi, murt. kutta. Pronominivartalolla e- on vastineet useimmissa uralilaisissa kielissä (ks. H. PaAsonen FUF 6 s. 114-; SKES I s.v. $\left.e^{-2}\right)$.

Onko sitten ajateltavissa, että 'ensimmäistä' merkitsevä sana pohjautuisi pronominivartaloon? Mielestäni hyvinkin. On tärkeätä huomata, ettei myöskään järjestyksessä seuraava ordinaalilukusana toinen perustu lukusanavartaloon. Juuri 'ensimmäistä' ja 'toista' merkitsevät ordinaalilukusanat ovatkin useissa kielissä muodostuneet aivan eri vartaloista kuin vastaavat perusluvut (vrt. RAVILA, teoksessa Verba docent s. 77): lat. unus, duo, mutta primus, secundus, engl. one, two $\sim$ first, second, ruots. en, två $\sim($ den) första, andra jne.; sellaiset kardinaalilukusanaan pohjautuvat 'toista' merkitsevät sanat kuin saks. (der) zweite, ransk. deuxième taas ovat myöhäisiä uudismuodostuksia. Samoin on laita yleisesti suomen etäsukukielissä. Niinpä- 'ensimmäistä' merkitsee lapissa ja mordvassa vasta-vartaloon perustuva sana, syrjäänissä ja votjakissa kummassakin yhdyssana, jonka osana on edellä mainittu otsa-sanan vastineeksi selitetty sana, unkarissa esi-vartalon sukulainen elsö, mordvassa, tšeremississä, votjakissa ja vogulissa (mordvassa ja votjakissa edellä mainittujen sanojen rinnalla) venäjästä lainattu sana (votj. pervoi jne.) (ks. esim. Z. Jókay Magyar Nyelv 25 s. 360—; Orbán mt. s. 74). 'Toista' taas ilmaistaan ainakin lapissa, syrjäänissä, vogulissa ja unkarissa muupronominiin perustuvilla muodostukssilla (ks. JókıY mp. s. 362; SKES II s.v. muu).

Suomen toinen, jolla on sekä ordinaalilukusanan merkitys 'der zweite' että pronominimerkitys 'toinen kahdesta, der andere', on ilmeisesti tuo-pronominin johdos, kuten on oletettu (vrit. BudENz Magyar Nyelvör 7 s. 337, OJANsuU Itämerensuomalaisten kielten pronominioppia [Turun yliopiston julk. I: 3], 1923, s. 53, JóKAY mp. s. 362, HaKULINEN SKRK ${ }^{2}$ I § 35). Äänneasu on aivan säännöllinen: 
*tō + inen $>$ toinen, vrt. suo $\sim$ soinen (virossa teine, mutta murteittain myös tõine, toine jne., ks. esim. V. TAULI Phonological Tendencies in Estonian, 1956, "s. 46; A. SAAREste Eesti keele mõisteline sõnaraamat, palsta $877-$ ). Kun $e$-pronominin merkitys näyttää olleen 'tämä' (ks. SKES ja HAKüLnen SKRK² I § 36), ovat ensi ja töinen nähtävästi alkuaan merkinneet 'tätä, tässä olevaa' ja 'tuota, tuossa olevaa' tjs. Molemmat tässä esiintyvät johtimet $(-n s i<*$-nte ja -inen) ovat ehkä alkuaan olleet mérkitykseltään lähinnä deminutivisia ja kehittyneet rajoittamaan kantasanan ilmaiseman merkityksen alaa (vrt. HaKUL.rNen SKRK ${ }^{2}$ I $\$ 52: 18$, § 51; RAvila mt. s. 82-). On hyvin ymmärrettävissä, että myös johdin -nsi<*-nte on voinut liittyä pronominivartaloonkin (vrt. OJANsuU Ims. kielten pronominioppia's. 33-). Kun sanat ovat olleet puhtaasti pronominaalisia eivätkä ole kuuluneet lukusanasarjaán, ei ole mitään outoa siinäkään, että ne ovat muodostuneet eri johdinten avulla. Ne ovat muodostanèet vastakohtaparin, jonka tehtävänä on ehkä ollut ilmaista 'lähintä, tämänpuoleista kahdesta' ja 'etäisempää, tuonpuoleista kahdesta'. Vasta myöhemmin, kun on entistä enemmän ilmennyt tarvetta käyttää järjestystä osoittavia sanoja sellaisistakin olioista ja esineistä, jotka eivät ole olleet näköpiirissä, nämä sanat ovat saaneet selvän ordinaalilukusanan menkityksen.

Pronominit $e$ - ja tuo eivät tietenkään ole olleet ainoat mahdollisuudet, joiden pohjalta on voitu kehittää 'ensimmäisen' ja 'toisen' ilmaukset. Eri kielet ovatkin käyttäneet eri keinoja, kuten olemme nähneet, ja ims. kielissäkin on myös esi-vartalosta kehittynyt 'ensimmäistä' meikitsevä sana. On siis aivan luonnollista, että suomalaisugrilaisissa kuten lukuisissa muissakin kielissä juuri 'ensimmäistä' ja 'toista' merkitsevät sanat ovat kirjavampia ja usein nuorempia kuin muut ordinaalilukusanat. On kuitenkin mielenkiintoista, että — jos tässä esitetty selitys osuu oikeaan — 'ensimmäistä' merkitsevä sana suomessa on muodostunut saman johtimen avulla, joka myös esiintyy yleisenä järjestyslukusanojen johtimena.

Sellaisiin tapauksiin, joissä ensi on merkinnyt 'edellistä, muihin verrattuna aikaisempaa' (esim. ensi $\sim$ toinen), perustunee ensi-sanan johdos entinen (samaan merkityksen kehitykseen liittyvät myös ennen, ennustaa, ennallaan jne.). Samaan tapaan on esi-vartalon pohjalita muodostunut edellinen. Kun ènsi on mexkinnyt 'lähintä', niin se on joutunut merkitsemään myös 'tästä lukien seuraavaa', esim. 
ensi yönä. Jälleen tarjoaa esi paralleelin, sillä eräissä murteissa sitä käytetään samalla tavoin, esim. Urj VesL esi yänä. Ensi-sanueen monimerkityksisyys lienee ollut yhtenä syynä siihen, että on ruvettu käyttämään superlatiiviin perustuvia muodostuksia ensimmäinen ja ensinnä, kun on tarkoitettu nimenomaan ordinaalilukusarjan ensimmäistä jäsentä. Näitä voidaan verrata esim. ruotsin sanaan (den) förste, - $a$ 'ensimmäinen', joka on superlatiivi samasta vartalosta, josta (den) förre, - $a$ 'edellinen, entinen' on komparatiivi (ks. E. HeLlquist Svensk etymologisk ordbok ${ }^{3}$ ss. 262, 263).

\section{Osmo Ikola: On the Finnish Words for "first" and "second"}

In the Finnish Etymological Dictionary, the Fimnish word ensi ('first, next') has etymological equivalents only in the Baltic-Finnic languages. The word occurs also in Lappish, but there it is a loanword. Reference is made to the explanation given by G. Orbán (A finn-ugor nyelvek számnevei, Bratislava 1932, p. 72) that ensi consists of the: ancient pronominal stem ${ }^{*} e$ - plus the same diminutive derivative suffix $-n s i<{ }^{*}$-nte that forms the suffix in the ordinal numbers from three onward: kolmas $<k o l m a n s i<{ }^{*} k o l m a n t e$ (ef. essive sing. kolmantena). This explanation is supported by the fact that toinen 'second, other' is probably a diminutive form derived from another pronoun tuo ('that'). Earlier ensi and toinen formed the binary contrast, 'nearer of two things' versus 'more remote of two things'. Only later did these words acquire the meaning of the ordinal numbers. In other Finno-Ugric languages, as well as in many other languages, the words for 'first' and 'second' have, similarly, developed from other pronouns or words denoting locality. So, in some Baltic-Finnic languages and Finnish dialects, the word for 'first' is derived from esi- 'one that is in front of something'.

Entinen 'former', ennen 'earlier', ennustaa 'to foretell', ennallaan 'as before, unchanged' are derivatives of ensi which happened to occur in environments where the meaning was temporal: 'former', 'earlier'. As $\epsilon$ nsi meant 'the nearest (one)' it also got the meaning of 'the next (one)', e.g. ensi vuonna 'next year'. The fact that the word has several different meanings may have caused it to acquire the form of a superlative adjective ensimmäinen, when it means 'first'. 